\title{
Cloth(ing) for the dead: case study of three designers' green burial practices
}

\author{
Gwendolyn M. Michel ${ }^{*}$ and Young-A Lee
}

\author{
${ }^{*}$ Correspondence: \\ michelg@iastate.edu \\ Department of Apparel, \\ Events, and Hospitality \\ Management, lowa State \\ University, 2302 Osborn \\ Drive, Ames, IA 50011-1078, \\ USA
}

\begin{abstract}
The aim of this study was to explore the current green burial clothing movement by examining three designers' work using a multi-case study approach. Green burial incorporates a sustainability concept into funeral practices. Cradle-to-cradle, as opposed to cradle-to-grave, is a model for sustainability practices that plan for the product lifecycle to continue after consumer use of the product has concluded. The works of Mark Mitchell, Jae Rhim Lee and Pia Interlandi were selected for the three cases of green burial practices in the context of cradle-to-cradle design using the five steps to eco-effectiveness. They used natural fibers in their clothing designed for green burial, and created clothing intended to be non-toxic to the soil and groundwater when buried with the body. Jae Rhim Lee's designs included a mushroom culture to aid in decomposition of the body and remediation of toxins found in the body, resulting in compostable soil. In addition to the multi-case study, this study also examined a wide variety of primary and secondary research literature from the fields of forensics, archaeology, and textile science to identify current purchase options for green burial clothing and to inform suggestions for future development of green burial apparel within the context of cradle-to-cradle design. This study also urged the importance of consumer awareness in terms of the choice of burial clothing if considering the full implementation of the cradle-to-cradle design principles into green burial clothing practices. The findings of this study call for further research on sustainability in burial clothing.
\end{abstract}

Keywords: Burial clothing, Cradle-to-cradle, Fibers, Green burial, Sustainability

\section{Introduction}

An individual's impact on the environment continues after death, quite literally, in fact. The manner of disposition of the body, whether by cremation or burial, leaves its remnants in the form of organic material, bone, ash, soil, or smoke. The green (or natural) burial movement has grown in the UK over the past 20 years (Clayden and Dixon 2007) and recently in the US and Canada. Both the UK and US have seen increasing use of simple, biodegradable coffins or the use of shrouds alone, in lieu of caskets or coffins. As of 2013, in the US the most common form of disposition was burial, followed closely by cremation (National Funeral Directors Association 2015). In North America, a conventional burial and funeral service conducted by a mortuary or funeral home typically includes replacing the blood of the deceased with formaldehyde embalming fluid to slow decay, use of an upholstered, finished wood or metal casket, and concrete or metal liners

(C) The Author(s) 2017. This article is distributed under the terms of the Creative Commons Attribution 4.0 International License (http://creativecommons.org/licenses/by/4.0/), which permits unrestricted use, distribution, and reproduction in any medium, provided you give appropriate credit to the original author(s) and the source, provide a link to the Creative Commons license, and indicate if changes were made. 
or vaults to encase caskets below ground, comprising what one funeral professional has called "a desperate attempt to stave off the inevitable" (Doughty 2014, p. 159).

This study did not seek to recommend forgoing embalming or cremation, but does present recommendations for textiles and clothing that may accompany the body in green burial. By examining previous studies in archaeology, fiber and textile science, forensics, UK and North America's burial practices, and the types of clothing and textiles currently available for green burials, this study has developed recommendations for the next generation of sustainable burial practices. The green burial movement is an environmentally friendly alternative to the funeral industry's most common practices. Green burial prohibits toxic embalming fluids that can infiltrate groundwater and the use of casket and coffin materials that do not easily biodegrade and encourages planning for reduced environmental impact and increased sustainability (Green Burial Council 2015).

Also among green burial practices are limited use of pesticides, fertilizers, herbicides, and electric and gas-powered lawn maintenance equipment and a recommendation for burials at a depth of 3-4 feet, instead of the current industry standard ( 6 feet), for more "rapid, uninhibited, aerobic decomposition, resulting in the decay that creates the basis for fertile soil" (Green Burial Council 2016, p. 4). There are currently 93 green burial cemeteries in the US and over 200 in the UK (Hockey et al. 2012; Marsden 2016). The use of burial containers, including cement or plastic vaults to encase caskets or coffins, is not required by any US law, but is a common requirement in modern cemeteries; some have now begun to allow green burials, but not all (Doughty 2014; National Funeral Directors Association 2016).

Although not everyone chooses to embalm the dead before disposition of the body, the use of formaldehyde embalming fluid is extensive in the American funeral industry and is a known cause of cancer among funeral industry workers (e.g., Hauptmann et al. 2009). Further, when the human body is drained of blood, to replace that blood with formaldehyde embalming fluid, both fluids become part of the wastewater stream of the funeral home, entering the municipal sewer system (Chiappelli and Chiappelli 2008; Doughty 2014). Perhaps worst of all, applying the US Environmental Protection Agency's criteria for assessing toxic waste, Chiappelli and Chiappelli (2008) conclude, "When you add embalming fluid, which is toxic, to a dead body, which is nontoxic, the whole becomes toxic waste" (p. 26).

The alternative to burial is cremation, which has seen a growth in China since the 1950s, with the implementation of government reforms designed to promote cremation and preserve land for farming and living (Xue et al. 2016). In the US since the early 1960s, when the Catholic church overturned its ban on cremation and author Jessica Mitford wrote The American Way of Death, cremation has been promoted as a modern and cost-effective choice (Doughty 2014; Kelly 2012; Xue et al. 2016). The cremation rate in China reached 49.5\% in 2012 (Xue et al. 2016, p. 29) and Kellaher et al. (2005) state that cremation "is now the most common form of disposal in the UK" (p. 239). The Cremation Association of North America (2015) found that the US cremation rate reached $46.7 \%$ in 2014 and has projected that by 2019 , US and Canada's cremation rates will rise to $52.9 \%$ and nearly $73 \%$, respectively. However, the downside to cremation, as presently practiced in China, UK, and North America, include the use of a large quantity of fossil 
fuels, creation of greenhouse gases, and airborne pollution, including the release of mercury from dental fillings (Doughty 2014; Kelly 2012; Xue et al. 2016).

Rethinking the nature of burial as a permanent preservation of the body, green burial invites us to reconsider the final selection of clothing for the body. This study puts forth that the grave is not truly the final resting place of the body, instead merely a temporary stopover in an ongoing process of transition. Therefore, so too is the grave a temporary place for those clothing and textiles chosen to envelop the body, and their inherent fibers of which they are composed.

At the present time, it is particularly important to study sustainability in this context because individuals' life expectancy has been increasing, creating an increased need for sustainable mortuary and burial practices (Doughty 2014; Zimmerman 2013). Natural burial is an alternative when deeply considering the betterment of our next generation. Although apparel scholars have long addressed sustainability in the production and consumption of clothing and textiles, no academic research has been conducted on green burial clothing within the field of textiles and clothing scholarship. There is still a gap in clothing-related literature, examining the full lifecycle of clothing that ties with human beings' entire life span using cradle-to-cradle approach. Therefore, this study focused on exploring the current green burial movement by examining three cases of green burial clothing designers, two in the US and one in Australia, using primary and secondary sources. This study proposed the following specific research questions: (1) What are the present purchase options for green burial clothing? (2) In terms of minimizing environmental impacts and embodying cradle-to-cradle design, what kinds of fabrics and fiber types are the best for green burial clothing, shrouds, and coffin/casket linings? and (3) How can clothing and textiles for green burial practices become more sustainable?

The three designers examined in this study approached clothing the body for burial from a perspective of green burial. Mark Mitchell of Seattle, Washington used a background in theatrical costume to inform his aesthetic in creating a collection of one-ofa-kind custom burial ensembles from fine fabrics using couture and heirloom-sewing techniques. Jae Rhim Lee of Boston, Massachusetts melded both art and science in her creation of the Infinity Burial Suit and Mushroom Decompiculture Kit launched by funeral start-up, Coeio, in late 2015. Australian scholar, artist, and funeral celebrant, Pia Interlandi combined fashion design, fiber science, forensics, and practicality in her use of water-soluble fibers, experimental burials and exhumations of clothed pigs, and her line called "Garments for the Grave" designed with easy dressing of the human dead in mind.

Within the field of textiles and clothing scholarship, it is recognized that elements of dress include more than clothing. When referring to all elements of adornment and modification of the body, the term dress is preferred among clothing and textiles scholars (Hillestad 1980; Roach-Higgins and Eicher 1992). While the present study acknowledges the potential for environmental impact that all aspects of dress (i.e., the addition of cosmetics and jewelry) may have, this study only limits its focus to the examination of textiles for burial. The role of other aspects of dress in green burial may be a topic for future study. 


\section{Literature review}

Janet McCausland, a director of Canada's Natural Burial Association, describes natural burial as,

... a way of combining an ecofriendly interment with land conservation. It's the return to the Earth of a body free of embalming chemicals, in a biodegradable shroud or local wood casket. A native tree or shrub may be planted, or a flat native stone left, to mark the grave in a natural, protected burial ground. (McCausland 2008, p. 6)

In a study of UK burial grounds, Hockey et al. (2012) describe natural burial grounds as, "sites where, for example, traditional headstones are not permitted...embalming and hardwood caskets are eschewed and...preserving or creating new habitats is a priority" (p. 117). To further define natural burial grounds, as they exist in the UK, Hockey et al. (2012) add,

Digging holes in a field in which to bury corpses is not the same as driving sheep onto grazing land. Yet in some natural burial grounds, these activities occur in parallel. (p. 120)

Kim et al. (2008) also note that these burial grounds "often [take] the form of a managed woodland or meadow". (p. 1)

Presently, there are a handful of online options for biodegradable coffins and shrouds for natural burial for direct purchase by consumers (i.e., Bellacouche wool felt coffins and shrouds in the UK; in the US, Kinkarako burial and cremation shrouds, and organic, unbleached cotton shrouds from The Natural Burial Company). Of those items, biodegradable coffins are the most common, followed by shrouds and shrouding boards (a board to which a shrouded body is strapped or tied for carrying and for lowering gracefully into the grave). Although McCausland (2008) mentions the use of a biodegradable shroud or casket, without mention of clothing, it seems logical to conclude that if the principles of green burial preclude the use of embalming and hardwood caskets, they would also include a preference for biodegradable textiles in apparel for the deceased. Commercially produced apparel for green burial was next to impossible to find. Just three makers of green burial clothing were identified through thorough reviews of secondary sources. It was those three designers who became the focus of this multi-case study.

Researchers have explored consumers' attitudes towards death and disposition of the body with a variety of perspectives and methods in recent years. The green burial movement in the UK has received particular interest from scholars. Hockey et al. (2012) investigated burial grounds owners', managers', and users' attitudes regarding the absence of traditional material culture in green burial grounds in the UK. Kellaher et al. (2005) examined emerging ritual practices for disposition of cremated remains in the UK. Trompette and Lemonnier (2009) traced the history of the practice of embalming in the twentieth century, as a technical innovation co-opted from the medical community by a newly professionalized death care industry in France. In her analysis of the meaning of the human dead body in American popular culture, Kelly (2012) notes, "Over the 
last 150 years American death care has positioned human death outside of the cycles of nature". (p. 38)

From the stance of conservation biology, Stowe et al. (2001) suggested that if consumers are brought to "recognize and de-institutionalize toxic burial customs," it will lead them to return into historically greener practices that are sustainable and facilitate the processes of grieving and coping with loss much better than contemporary practices ( $\mathrm{p}$. 1818). Stansberry (2004) conducted a qualitative study investigating unique burial practices in an area of Southern Appalachia in the US, and found their erosion was caused by the adoption of modern funeral industry practices. From an ethnographic perspective, Picton (2009) documented the use of traditional textiles in Nigerian funerary practices, including as doorway drapes for mourners' homes, mourners' costumes for masquerade, and wrappings for the deceased. From a material culture perspective, Harper (2012) explored contemporary British and American grave goods (e.g., clothing, other items of dress, letters, photographs) placed with the deceased by the bereaved. Although modern burial customs, including the green burial movement, have been examined in recent years, none has focused exclusively on clothing and textiles for green burial.

McDonough and Braungart's (2002) concept of cradle-to-cradle (C2C) design recommends a reevaluation of the typical product lifecycle: rather than landfilling or incinerating products no longer used, resources may be returned to the use stream in an unending cycle, also called "waste equals food." McDonough and Braungart call this cycle $\mathrm{C} 2 \mathrm{C}$, using the example of a cherry tree to illustrate:

A cherry tree makes many blossoms and fruit to (perhaps) germinate and grow...the extra blossoms are far from useless. They fall to the ground, decompose, feed various organisms and microorganisms, and enrich the soil. Around the world, animals and humans exhale carbon dioxide, which plants take in and use...Nitrogen from wastes is transformed into protein by microorganisms, animals, and plants... The earth's major nutrients-carbon, hydrogen, oxygen, nitrogen-are cycled and recycled. ( $p$. 92)

In the case of human burials, the process of decomposition and decay can be viewed as one step in a recurring cycle of transformation of nutrients into food. A green cemetery can be used for restoring natural habitat and woodlands, and for animal grazing. A traditional cemetery in the US, Canada, and the UK, with its manicured lawns, pesticides, and fertilizers cannot, nor can its soil be easily considered for reuse.

McDonough and Braungart (2002) describe the majority of sustainability practices as "being less bad," rather than embodying the $\mathrm{C} 2 \mathrm{C}$ approach holistically. They quote Robert Lilienfeld and Willam Rathje (Use Less Stuff: Environmental Solutions for Who We Really Are, 1998) in defining what it means to "be less bad":

'Recycling is an aspiring, alleviating a rather large collective hangover...overconsumption.' Or again, 'The best way to reduce any environmental impact is not to recycle more, but to produce and dispose of less.' (p. 50)

Using fibers and textiles that would readily biodegrade and forgoing embalming could be held up as examples of "being less bad" in the context of green burial. Incorporating use of clothing and textiles that nourish the biodiversity of the soil in which the body 
is buried would result in true $\mathrm{C} 2 \mathrm{C}$ green burial. Suggested textiles and fibers that may encourage microbial activity, aid decomposition, and fertilize the soil include natural fibers and corn-starch polymers, both known for their biodegradability.

McDonough and Braungart (2002) encourage consumers and industrial designers to move away from "less bad" practices and towards those of $\mathrm{C} 2 \mathrm{C}$ in a five-step process. Incorporating their "five steps to eco-effectiveness," key principles of the $\mathrm{C} 2 \mathrm{C}$ approach, into green burial practices would take green burial to the next level for the betterment for environment and the people. Those five steps include: (1) get "free of" known culprits, (2) follow informed personal preferences, (3) create a "passive positive" list, (4) activate the positive list, and (5) reinvent, which used as a guide for data analyses in this study.

Clothing for burial can include either clothing made for the living, such as the deceased's own clothing (which may include clothing purchased for the burial), or alternatively, specialty burial clothing purchased from funeral homes as part of funeral services. Clothing specially designed for burial necessity typically has flexible fabrics, openings at the back for easier dressing of the deceased, and higher necklines and longer sleeves than normal clothing, to conceal the skin of the deceased during viewing or visitation (Ethel Maid, Inc., "Why Burial Garments?," n.d.; O'Connor 2013; Zinn, n.d.).

To illustrate the inherent challenge for the living to dress the dead, Brownlee (2013) explains, "[C]lothing is made to be put on autonomously: a shirt that you can effortlessly shrug into and button up while you're alive can be incredibly difficult to dress a corpse with..." (para. 5). The trademarked term, "tribute fashions," (owned by manufacturer Rita Barber, Inc. of Abilene, Texas), refers to "burial clothing, namely, dresses, suits, pants, shirts, ties, jackets and coats" (Justia Trademarks, n.d., para. 15). In a press release dated December 5, 2014, Vera Lee Garments of Fort Worth, Texas, also a burial clothing manufacturer, announced that it had purchased Rita Barber, Inc (n.d.). Vera Lee Garments now uses the term "tribute fashions" as well (Rita Barber, Inc. 2014). Burial clothing manufactured by Rita Barber and Vera Lee is only available wholesale to funeral directors and funeral homes in the US.

A third manufacturer, Ethel Maid, Inc., an American company founded in 1931, specializes in a range of burial clothing and accessories, also only available wholesale to funeral directors and funeral homes (Ethel Maid, Inc., "Ethel Maid History," n.d.). Information on fiber contents of apparel manufactured by Ethel Maid, Inc. was not readily available on the company's web site but Ethel Maid's women's dresses appear similar to the polyester and nylon dresses of American burial clothing manufacturers Rita Barber, Inc and Vera Lee. All three manufacturers offer women's gowns, suits, negligees, robes, pajamas, panties, slips, and hose, and men's suits, dress shirts, pajamas, robes, undershirts, briefs, boxer shorts, and socks. Ethel Maid's men's dress shirts were listed as being Van Huessen [sic] brand. Unlike Ethel Maid and Rita Barber, Vera Lee carries men's dress slacks in white for Latter-Day Saints services and velvet robes for cremation (fiber contents for these garments, like all apparel on the Vera Lee web site, were not published).

Rita Barber has a limited line of $100 \%$ silk garments: gowns, pajamas and robes for women, and a smoking jacket for men. Also different from Ethel Maid and Vera Lee, Rita Barber sells men's and women's suits and dress shirts, neckties, and men's dress shoes for funeral home staff. Both Rita Barber and Vera Lee sell pallbearer gloves. For 
this study, all three manufacturers were contacted by email with requests for fabric and fiber information on their apparel and no responses were received. No prices for apparel were available online, as these manufacturers do not sell direct to the public and only sell wholesale to funeral homes. Visual and content analysis of both Ethel Maid and Rita Barber's web sites has led to the conclusion that polyester and nylon fabrics are the most common fabrics in commercially produced women's burial clothing (e.g., ethelmaid. com; ritabarber.com).

All three designers (Mark Mitchell, Jae Rhim Lee, and Pia Interlandi) who were chosen for this study subscribe to the idea that to dress a corpse in the specialty burial garments used by funeral homes reduces the "greenness" of a green burial because those are made from petroleum-derived fibers that do not decompose. Choosing sustainably produced, biodegradable fabrics intended to decay with minimal negative environmental impact, perhaps even nourishing the soil, would seem to be the "greener," and more sustainable, choice.

\section{Methods}

This study especially focused on examining three clothing and textile designers' work at the forefront of the green burial movement using a case study approach. Each case was focused on: (1) reviewing the methods and inspirations of the designers and (2) examining their work in the context of cradle-to-cradle $(\mathrm{C} 2 \mathrm{C})$ design using the five steps to eco-effectiveness.

A case study approach was chosen for this study because it facilitates exploration of a phenomenon within its context using a variety of data sources. This ensures that the issue is not explored through one lens, but rather a variety of lenses, which allows for multiple facets of the phenomenon to be revealed and understood. Stake (1994) calls the case study "not a methodological choice, but a choice of object to be studied" (p. 236). This study applies its initial findings from the review of research literature and Internet content to a collective case study, that is, the study of multiple cases. The reliability of Internet content, including secondary sources, for exploring a wide range of topics has been supported by the work of Dholakia and Zhang (2004), Kozinets (2002), Lugosi et al. (2012) and Touchette et al. (2015).

In this study, the multiple cases were the three designers of burial clothing. The multiple case study as a method for "enhancing the external validity or generalizability of [researchers'] findings" (Merriam 2009, p. 50) is well supported by the work from Huberman and Miles (1994), Merriam (2009), and Merriam and Tisdell (2016). Three designers including a former theatre costumer, an artist/design scholar, and a fashion designer cum funeral celebrant were selected for the cases to incorporate a transnational perspective on green burial practices and to highlight three different ways to approach $\mathrm{C} 2 \mathrm{C}$ design practices in green burial. To carry out this study, one assumption that natural fibers (e.g., organic cotton, wool, silk) are ideal choices for sustainable burial was proposed. This study sought to validate this assumption, identify further options, and highlight three designers' work in green burial apparel design.

Data gathering consisted of two parts using secondary sources: surveying research literature and exploring other additional sources via Internet to look for current green burial clothing and textile options available to consumers. Preliminary data gathering 
consisted of an Internet search for consumer purchase options for green burial clothing, using the search engine by typing terms such as "funeral clothing," "burial clothing," "burial garments," "natural burial clothing," "green burial clothing," including the above phrases with the words "clothes" and "apparel" substituted for "clothing." The search was conducted in English only. Sources found included American and UK-based companies specializing in clothing and shrouds for burial and were logged in an Excel spreadsheet. Online sources of data included the designers' professional web sites, news articles, videos, and blog posts highlighting their work and featuring interviews of them.

Each designer was also contacted by email and asked to provide additional information about his or her design process and sustainable design practices (e.g., original intention or inspiration of designers' work, use of undyed, unbleached, naturally colored fibers and their rationale, use of modern dyed fibers or textiles in their designs in the future, incorporation of traditional natural dyes made from plant, mineral, or animal-based materials in their work in the future). Two of the designers, Mark Mitchell and Pia Interlandi, responded to the researchers' queries. In the case of Mark Mitchell, the designer supplied answers to the researchers' questions by email, including follow-up questions, and later, an interview by telephone. In the case of Pia Interlandi, the researchers were referred by Interlandi to her (2012) doctoral exegesis as the best source for detailed information on her design and research practices. In the case of Jae Rhim Lee, her business partner, Mike Ma was able to provide answers to the researchers' questions by email. Data from the designers via personal communication and secondary sources were analyzed to determine what aspects of $\mathrm{C} 2 \mathrm{C}$ design principles were incorporated into the work of each designer and what inspired each designer to design and produce clothing for green burial.

\section{Results and discussion}

This study found three sustainable burial clothing projects in current or recent development. Each designer's work is discussed in turn, followed by a discussion of findings and conclusions in how this multi-case study provides directions for future scholarship on the topic of sustainability practices in selection of clothing and textiles for funeral practices. Using information gleaned from the research literature in the forensics, fiber and textile science, and archeology fields, future recommendations are made for clothing and textiles for green burial.

\section{Case 1: Mark Mitchell's burial clothing with natural fibers}

In 2013, artist and former theatrical costumer Mark Mitchell of Seattle, Washington exhibited a collection of nine ensembles titled "Mark Mitchell: Burial." The collection, now referred to as Burial I, was inspired by Mitchell's background in costume design, and his experience living through the height of the AIDS epidemic in Seattle. Before designing Burial I, Mitchell's only prior burial design was a fabric and textile funeral urn he created for a 2008 exhibition curated by Greg Lundgren of Lundgren Monuments in Seattle (personal communication, November 13, 2015). Luxury fabrics and finishing techniques were among the foci of Mark Mitchell's 2013 collection of burial clothing, “... highly-detailed clothing from silk and other $100 \%$ natural materials that is suitable for burial, cremation, and burial-at-sea..." (Mark Mitchell Burial, "About," n.d.). 
In the film "Mark Mitchell: Burial" (Stone-Francois 2013), Mitchell described his transition from theatrical costume designer to tattoo artist at the age of 30. During this period of his life, Mitchell described himself as having "a lot of social problems," including drinking and using drugs to excess, until he came to realize he might survive the epidemic, unlike many others he had known:

And then I had to go oh, whoa, wait a minute, you know. If I'm going to live, I have to live this life completely differently. I can't live in this dark place and live for a long time. Cause it's not fair to the people that did die. They didn't get a chance to have a good life, you know. I need to have a good life. (Stone-Francois 2013)

Mitchell then devoted himself to a life of purpose, while planning for the future, and making the best of his life. His work with burial clothing allowed him to deal with the trauma of his survivor guilt relating to the epidemic and "find a way forward."

The opening reception for Mitchell's 2013 exhibition at the Frye Art Museum in Seattle, Washington during September 21 through October 20 featured nine live models dressed in the Mark Mitchell Burial collection, lying on large mirrors on the floor of the gallery, eyes closed as if dead. The burial clothing worn by each model was inspired by the individual and created especially for him or her, making an idealized or iconic representation of the model (personal communication, November 13, 2015).

Mitchell's burial clothing uses predominantly undyed and unbleached natural fibers and fabrics of mostly silk and wool. Overall, his aesthetic for the collection is theatrical with elements of glamour reminiscent of old Hollywood and nineteenth century Parisian couture. As Mitchell himself explains, "My choice of techniques for work like Burial [I] is limited to late 19th and early twentieth century dressmaking techniques. I use slow, finehandsewing techniques, the best natural materials, and don't take any shortcuts" (personal communication, August 1, 2015). Pieces in the Burial I collection featured classic details such as rows of fabric covered bridal-style buttons, hand-embroidered tattooinspired motifs, and hand-knitting.

The first exhibition was well received and Mitchell began a second collection, Burial II, which was to be "hand sewn, without sewing machines" (personal communication, August 1, 2015). However, diverging from the first Burial collection, Burial II was not planned as a collection of burial clothing. Mitchell has stated that he did not plan to make any more burial clothing, except by commission, adding, "My artwork has taken another turn, and it's unlikely that I will revisit burial clothing as a subject for some time. Burial II, my new work is more object-based than garment-based" (personal communication, August 1, 2015).

Mitchell's use of luxury fabrics and finishing techniques, and unbleached, undyed natural fibers in Burial I to create one-of-a-kind looks for his model/muses resulted in burial clothing that both honors the deceased and the environment. Of McDonough and Braungart's (2002) five steps to eco-effectiveness, two steps were well addressed in Mitchell's designs: Step 1 (Get "free of" known culprits) in that known culprits, synthetic fibers in this case, were not used, and Step 2 (Follow informed personal preferences) in that Mitchell's materials were chosen from the best natural fabrics available and with a particular aesthetic sense. As McDonough and Braungart wrote in their description of 
Step 2, "It would not do to select unattractive things just because they had more environmental authority" (p.169).

\section{Case 2: Jae Rhim “JR" Lee's burial suits with mushrooms}

Artist and scholar, Jae Rhim "JR" Lee is the creator of the Infinity Burial Project, burial garments and shrouds for people and pets with an added fungal culture to aid decomposition. After founding and directing the MIT FEMA Trailer Project in 2008, which "examined the environmental, social and political history of FEMA Trailers deployed in the wake of Hurricanes Katrina and Rita," Lee discovered that hurricane victims rehoused in FEMA trailers were becoming ill from the trailers' formaldehyde off-gassing (ACT at MIT, "Jae Rhim Lee," n.d.; Creative Capital 2015). This new awareness of the toxicity of formaldehyde inspired Lee to investigate an alternative to the American funeral industry's formaldehyde embalming process (Creative Capital 2015).

Lee created her burial suit and its accompanying fungal strain for the purpose of removing toxins from the decaying body, preventing them from causing environmental harm as the body decays underground. Lee's selective breeding of a fungal strain that could consume dead human tissue (bred on dead skin cells and fingernail clippings) was created for the purpose of removing and remediating toxins that exist in the human body, preventing them from entering the ecosystem during decomposition in a process called mycoremediation (Kulshreshtha et al. 2014). By feeding skin cells and hair to mushrooms, Lee cultivated a fungal strain intended to both produce edible mushrooms and remediate environmental toxins in the decomposing body (Creative Capital 2015).

In 2015, Lee joined with Michael Ma, a former senior executive for Bank of America, to found Coeio, a self-described "green funeral start-up." As of July 2016, Coeio now sells the Infinity Burial Suit, Infinity Burial Shroud, and the Infinity Casket Liner on its website (Coeio.com). The suit is available in organic unbleached or black cotton and comes in three sizes (small, medium, and large). The shroud is made of unbleached cotton and comes in two sizes: size 1 for those weighing less than $185 \mathrm{lb}$ and under 6 feet in height and size 2 for those individuals who are over $185 \mathrm{lb}$ and taller than 6 feet. The shroud and casket are made in New York and infused with mushroom spores (Coeio, "Coeio's infinity burial suit," n.d.). Coeio's product offerings for pets now include The Forever Spot pet shroud and pet bed with drawstring cover, "burial products that benefit the earth and are comforting to pet owners" (The Forever Spot, n.d., para.1). Like the Coeio products for humans, the pet products are made of organic cotton, infused with mushroom spores, and are now co-designed by fashion designer Daniel Silverstein (Coeio, "Coeio's infinity burial suit," n.d.; The Forever Spot, n.d.).

One of Lee's initial projects was the "Decompiculture Kit," a mushroom growing kit that allowed an individual user to selectively breed a strain of mushrooms to consume the user's hair, nail clippings, and dead skin cells. Spores from these mushrooms were then intended to be incorporated into the lining of the Infinity Burial Suit (Creative Capital 2015). Lee's goal in developing unique strains of fungi was twofold and took the concept of green burial two steps further than Mitchell and Interlandi: (1) for each user to have a strain of fungi best suited to his or her biological makeup for maximum efficiency in decomposition and (2) to have the mushrooms remove toxins stored in the body and prevent them from harming the environment after burial (Infinity Burial Project, n.d.). 
Currently, the suits, shrouds, and casket liners offered by Coeio contain mushroom mycelium, instead of spores, to make the products more shelf-stable, and are from multiple strains of mushroom that are found "all over the world" (Coeio, "Frequently Asked Questions," n.d., para. 25).

The original prototype of the Infinity Burial Suit covered the body from head to toe, like the current design, and was not only embroidered with yarn containing mushroom spores, but was also intended to be used in tandem with an alternative to embalming and a unique body cosmetic, body makeup described as "an Alternative Embalming Fluid, a liquid spore slurry, and Decompiculture Makeup, a two-part makeup consisting of a mixture of dry mineral makeup and dried mushroom spores and a separate liquid culture medium" (Infinity Burial Project, "Mushroom Death Suit," n.d., para. 1).

Like Mitchell's Burial I, Lee's designs and Coeio's product offerings incorporate the first two of the five steps to eco-effectiveness. Lee's work began as an alternative to formaldehyde embalming and Coeio avoids use of synthetic fibers and fabrics (Step 1: get "free of" known culprits). The mushroom death suit's (now the Infinity Burial Suits, Shrouds, and coffin liners) creation was informed by the properties of mushrooms for remediation of toxins in soil (Step 2: follow informed personal preferences).

\section{Case 3: Pia Interlandi's burial clothing for the grave}

The third green burial apparel designer examined by this study is Australian artist and scholar Pia Interlandi. A former fashion design student, Interlandi combined work in apparel design, fiber science, and forensic science for her doctoral dissertation research at RMIT University, graduating in 2013 and now working as a freelance funeral celebrant and designer of her green burial garments known as Garments for the Grave (Interlandi 2012). Interlandi was first inspired to think deeply about clothing for the dead after taking part in dressing her grandfather for his funeral.

Interlandi's research and design has had three main branches: experimental designs with water-soluble textiles; the Body Moulds series of sculptures; and The Pig Project, a forensic burial and exhumation project. Interlandi's work with each of these has culminated in her larger project, garments for the Grave burial clothing, currently in development. After dressing her grandfather's body in a traditional tailored men's suit for burial, Interlandi decided to create burial clothing that was designed for maximum ease in dressing and also quick to decompose with the body (Interlandi 2012; O'Connor 2013). The experience of dressing her grandfather's body in his best suit, a suit made for a flexible, living body to put on and wear with relative ease, left a strong impression on Interlandi. As Interlandi has pointed out, fashion design is all about clothing living bodies:

[W]ithin the fashion field, designers largely cater to living bodies; bodies with lived experience, dynamic movement, and sensory perception. This, of course, differs significantly from the realities of the dead body. (Interlandi 2012, p. 59)

The struggle to dress her grandfather for burial led Interlandi to design burial clothing that allows the living to dress their dead with ease and dignity, incorporating design elements that recognize these garments are to be worn by a body that may be inflexible and is being dressed for the final time. 
Interlandi's undergraduate research included work with water-soluble textiles and her doctoral research expanded this work to include a project with body-shaped molds and a larger project with a forensics team to clothe, bury, and exhume pigs (Interlandi 2012). In working with water-soluble textiles, Interlandi naturally found the effect of moisture during the construction process to be a special challenge. For example, she had to mind the sweat on her hands while sewing, make certain not to iron with steam, and to even avoid accidentally sneezing while working, as any amount of moisture would cause the fabric to dissolve (RMIT Architecture and Design 2013 ). Interlandi's Body Moulds project began with grass seeds and soil placed in body-shaped molds. Interlandi found that by placing the molds face down, a root pattern emerged on the front of the body, where the water had pooled due to gravity. This root pattern inspired an embroidery motif that she later used in The Pig Project and for Garments for the Grave, her line of burial clothing.

In The Pig Project, Interlandi worked with forensics entomologist Ian Dadour, in a residency with SymbioticA, The Centre for Excellence in Biological Arts, within the School of Anatomy and Human Biology at the University of Western Australia, Perth. Interlandi dressed 21 slaughtered pigs in burial garments of her own design, and buried and later exhumed them. In his lab, the pigs were exhumed at 50-day intervals over the course of a year to examine decay of different fiber types (e.g., cellulose, protein, synthetic). Fabrics and fibers used included hemp, hemp/silk blend, polyester embroidery, nut shell, and casein. Interlandi found that hemp disintegrated in 100-200 days, silk in 200-350 days, while polyester remained unchanged (RMIT Architecture and Design 2013).

Interlandi's culminating work is her collection titled Garments for the Grave. The Garments for the Grave are designed for ease of dressing and have been described as "... shrouds that recall cocoons and kimonos" (O'Connor 2013, para. 4). Rather than clothing designed for a living body that can move on its own, the Garments for the Grave function more as envelopes or wrappings for the body. The garments are designed with two primary functions, aside from covering the deceased: ease of dressing by family and/ or funeral professionals; and for dressing to be done as a ceremonial act, a part of saying goodbye to the loved one and facing death. The ceremonial process of dressing the body in Interlandi's garments is intended to be a slow process with many steps, one which "makes it somewhat easier to surrender it [the body] to nature" (RMIT Architecture and Design 2013). The body is laid on the garments, which are then folded and wrapped around the body, tied on with ribbons, drawstrings, and cords.

Interlandi's burial clothing was usually made from unbleached and undyed fabrics, but she would hand dye fabrics if desired (Marsden 2013). In August 2016, the Garments for the Grave online store (garmentsforthegrave.com.au) was not yet open, but Interlandi's website advertised burial clothing by special commission (piainterlandi.com). Applying the five steps to eco-effectiveness to her work, steps 1 and 2 were mostly fulfilled. In the case of step 1 (get "free of" known culprits), although Interlandi chose predominately natural fabrics and fibers, polyester thread was included in The Pig Project, for experimental purposes, to examine biodegradation. Her experimental work with PVA and use of embroidery designs that mirrored the imagery of the roots of the grass grown in the Body Moulds fulfilled step 2 (follow informed personal preferences) by use of her unique aesthetic. 


\section{Fibers and textiles options for green burial practices}

This study also explored the ideal choices of fabrics and fiber types for green burial, which would lead to a minimal negative environmental impact using the findings from previous academic studies. Studies such as Jurado et al. (2010) and Pangallo et al. (2013) can be used deductively to identify strains of bacteria and fungi that do not aggressively degrade paper or parchment, ruling out their inclusion in microflora selected for burial textiles. As Pangallo et al. (2013) found, bacteria and fungi worked with "complimentarity" (p. 298) in degrading the wool, silk, and linen of the burial clothing of the seventeenth century Austrian Cardinal. As discussed previously, Coeio's development of strains of fungus for decomposition are a further example of selection of fungi for decay and bioremediation.

As Solazzo et al. (2013) determined, soil types and microflora have notable impact on the biodegradation of wool fabrics. Additionally, natural dyes were found to have differing effects on biodegradability of the wool samples used in the study. Madder in particular was found to inhibit bacterial growth, suggesting that if natural dyes are to be preferred in burial textiles, madder should not be recommended.

Although Mitchell et al. (2012) found that polyester-cotton (65/35\%) shirting fabrics degraded more quickly than $100 \%$ cotton shirting fabrics, this study does not conclude that polyester-cotton is the better choice, from a sustainability perspective, due to the unknown, but presumed negative effects of degraded polyester fibers in the natural environment. The findings of Mitchell et al. (2012) further support this study's recommendations that the soil types of natural burial grounds should be analyzed including $\mathrm{pH}$ level. As they found, clay soil was more degradative than sand. This information can be used to guide selection of future locations for natural burial grounds. They also found that the more times fabric had been laundered, the weaker it was after burial.

According to Mitchell et al.s (2012) findings, this study recommends the use of clothing and textiles that are well-worn and not purchased new for burial, or if purchased specially for burial, clothing and textiles that have been laundered many times before burial. This study further suggests the use of the deceased's own clothing, perhaps clothing favoured by the deceased in life, rather than a treasured but worn-only-once wedding dress or suit made with synthetic fibers, and the use of vintage clothing and textiles such as handmade quilts. Incorporating the findings of Solazzo et al. this study recommends the analysis of soil types and microflora of natural burial grounds, which needs to be used to guide selection of burial textiles, tailored for the local makeup of the soil and its microbial flora.

Davidson and Mainfort's (2008) findings illustrate what remains of the nineteenth century clothing and accessories after 100-plus years of burial. It can be extrapolated that small metal components can be expected to remain long after the common types of fibers available (e.g., cotton, linen, wool, silk) in the nineteenth century have decayed. This finding leads to preliminary recommendations for green burial practices via the use of clothing and textiles made from natural fibers (e.g., cotton, linen, wool, silk) with a minimum of non-textile fastenings and other components. As Bellacouche suggests, a natural burial that uses wool felt made from the wool of local sheep reduces the carbon footprint of shrouds and eco-coffins (Bellacouche, n.d.). Therefore, locally sourced materials should be used whenever possible. Further, soil composition and local microflora in 
natural burial grounds should be examined so that textiles can be chosen to be compatible with desired rates of decay.

Based on the findings of Chen and Cluver (2010), this study suggests that conventional white cotton, while not ideal from a holistic sustainability perspective, can still be considered as a transitional choice if naturally colored cotton is unavailable to the consumer. White cotton's reduced mildew resistance results in quicker decay and biodegradation than naturally colored cotton. Incorporating the findings of Elanmugilan et al. (2013) and Ruixuan (2010), this study also recommends the use of corn starch in burial textiles to enhance biodegradability, as it would be consumed by microbes present in the soil. Interlandi's research has included experimental uses of water-soluble textiles. Water-soluble poly-vinyl alcohol (PVA), often used in sewing applications as stabilizer for machine embroidery, could be used to both clothe the body and feed the microflora in the soil. In selecting rate of decay, this study recommends that natural burial grounds decide whether the overall goal is quick decay with minimal impact on the environment ("being less bad") or C2C full lifecycle ("waste $=$ food"). The addition of microbial flora could be used to enhance decay (e.g., Coeio's Infinity Burial products), if properly identified as compatible with local flora (identification of which this study also recommends).

\section{Conclusion}

When we hold up the design practices of each of the three designers to the principles of $\mathrm{C} 2 \mathrm{C}$ design, and in particular the five steps to eco-effectiveness, we can see that each designer moves forward in a direction to support McDonough and Braungart's (2002) $\mathrm{C} 2 \mathrm{C}$ approach. All three designers, with their respective uses of undyed and natural fabrics have strived to lessen the potential negative environmental impact of the burial of the dead (steps 1 and 2). Jae Rhim Lee and Coieo takes step 2 in a unique direction, with the incorporation of a fungal culture into the green burial process, intended to not only aid in the decomposition process but also remediate the introduction of toxins from the body into the soil that surrounds it.

Regarding clothing and textiles for green burial, step 3 of the five steps to eco-effectiveness, "Creating a 'passive positive' list" has yet to be completed by scholars or this multi-case study's subjects. Each designer's work incorporates the intuitive assumption that synthetic fibers and dyes are not eco-effective. However, step 3 calls for the creation of three definitive lists of materials to use and materials to avoid: (1) The X list: substances known to be "the most problematic...teratogenic, mutagenic, carcinogenic, or otherwise harmful in direct and obvious ways to human and ecological health"; (2) The grey list: "problematic substances," those "that are not quite so urgently in need of phaseout," plus ones "essential for manufacture, and for which we currently have no viable substitutes," and (3) The P list, the list of "positive" or "preferred" substances, those that are "healthy and safe for use" (p. 174). Ideally, all the steps in the process of manufacturing textiles selected for green burial can be identified, including any chemicals used throughout the supply chain (from fields to finishes), and the textiles can be listed on either the grey list or the P list. This step may seem daunting, but McDonough and Braungart (2002) explain, "...this stage is the beginning of real change, and the inventory process can galvanize real creativity. It may stimulate the development of a new product line...[and] represents a paradigm shift" (p. 177). 
Step 4 (Activate the positive list), according to McDonough and Braungart (2002), "is where redesign begins in earnest, where we stop trying to be less bad and start figuring out how to be good" (p. 177). This is the step where the information gained in the creation of the $\mathrm{P}$ list is put into active use as designers select materials from the list and begin to implement them. Step 5 (Reinvent) is a larger reevaluation of the purposes for which the positive list was created. To explain what they mean by "reinvent," McDonough and Braungart suggest that instead of working to design cars that meet low emissions standards, industrial designers could alternatively "design a new transportation infrastructure" altogether (p. 179). To apply this step to the selection of clothing and textiles for green burial, to reinvent in this case would be to reevaluate green burial and sustainability in funeral practices as a whole: from pre-burial practices to post-burial use of the land.

Each of the three designers addressed here makes a valuable and unique contribution to the green burial movement. With their respective designs for clothing and textiles for green burial, Mitchell, Lee, and Interlandi propose new ways of looking at the grave as the final resting place for the body and the goods that accompany it. As the green burial movement encourages the living to consider their final impact on the environment (i.e., how their physical remains interact with and affect the soil in which they are buried), the selection of clothing and textiles that are buried with the body are an inextricable part of this impact.

Mark Mitchell's designs are intended to cause a minimum of harm to the life in the soil around the body. Pia Interlandi's work does the same, while including the concept of nourishment for those organisms that will consume the body and textiles. The Decompiculture Kit of Jae Rhim Lee takes the concept of nourishment even further, with mushroom strains that not only decompose the body but also remediate toxins found in the body, preventing them from causing harm to the ecosystem around it. Each of these three designers considers the impact of his or her designs on the soil around the body that wears them, carefully selecting fabrics that will decompose in harmony with the corpse and its final resting place. 'The body is a gift,' Interlandi says. 'It's a big bag of nutrients and water and protein. When you place it back into the earth, I think the garment is almost like wrapping paper"' (O'Connor 2013, para. 2).

This study sought to explore the current purchase options for green burial clothing, fabrics and fiber types that are best for green burial clothing, and the way clothing and textiles for green burial practices become more sustainable. As of now, few options are available for purchasing green burial clothing in the market. Based on the selected designers' case study and literature reviews, we suggest using natural fibers (e.g., hemp, silk, wool) that decompose easily with pre-identified soil types and microflora for best green burial practices. In addition, we provide suggestions for future development in green burial apparel design incorporating the five steps to eco-effectiveness.

When fabrics composed of biodegradable fibers are used in burial clothing, they can be transformed into food and fuel for organisms within the soil, leaving little trace of their former existence as fibers. If the soil used as the grave is not harmed by the interment of the body, that soil can have future uses beyond use for a grave. We may not like to consider what will become of a modern day grave in centuries to come, but as the planet's population grows, today's burial grounds may be transitioned into other uses, 
such as housing the living, farming, or even grazing for livestock. The care and use of the land that holds today's graves will be left to future generations. If consumers today choose green burial and make choices that feed the earth, as in the $\mathrm{C} 2 \mathrm{C}$ approach, future generations may have more options to choose from when deciding what to do with land that has served as burial grounds. Whether they choose to preserve and protect those grounds, or use them for other purposes, green burial can allow future generations greater flexibility in how they will use the land that our living have left to them.

\section{Implications for future study}

Suggestions for future research include experimental burials to assess decay of different fabric and fiber types and continued fungal and other microbial research to identify beneficial soil qualities and microbe balance to pair with body for $\mathrm{C} 2 \mathrm{C}$ benefit. Suggestions for the green burial movement and funeral professionals include planning for future use of burial grounds, bones, and grave goods, in the decades and centuries post-burial, and to decide whether speed of decay is of import, or only its impact.

This study primarily relied on secondary sources of data to understand the current phenomenon of green burial movement by examining three designers' green burial practices. Future research is urged to explore various ways to identify consumers' needs for green burial practices. Rather than using the secondary data currently available in the market, future studies are suggested using both quantitative (e.g., survey) and qualitative (e.g., interview) approaches to thoroughly assess consumers' attitudes towards green burial. This will lead to provide empirical suggestions for better marketing and education for consumers in the areas of green burial and burial clothing.

Current green burial practices have only just begun to move in the direction of $\mathrm{C} 2 \mathrm{C}$ design for burial clothing. The modern funeral industry, with its emphasis on preservation and resistance to change, has shown reluctance to embrace the natural death care movement (Doughty 2014). Therefore, it seems more likely that the choices in burial clothing that American consumers have available to them will have to be brought to their awareness in alternative ways. The next step is for consumers to be made aware of the possibilities for green burial garments and for designers to rise to fill this need. When designing clothing for green burial, fibers and textiles, including dyes, can be selected with the nourishment of microflora in mind. Clothing design for green burial can incorporate the principles of $\mathrm{C} 2 \mathrm{C}$ design, resulting in use of fibers and textiles that acknowledge the grave as never really having been a site of eternal, changeless rest, but supporting it in its role as a place of active transformation of the body into food and energy for the soil around it.

\section{Authors' contributions}

GM originated the research idea, carried out research and drafted the manuscript. YL guided research design, data analysis and interpretation, manuscript draft and its revision. Both authors read and approved the final manuscript.

Competing interests

The authors declare that they have no competing interests.

Received: 29 February 2016 Accepted: 20 October 2016

Published online: 28 March 2017 


\section{References}

Bellacouche, (n.d.). Leafcocoon wool coffin for natural burial. http://bellacouche.com/soft-eco-coffin/leafcocoon-woolcoffin/. Accessed 28 July 2016

Brownlee, J., (2013). These clothes will let you decompose in stylish grace. http://www.fastcodesign.com/3018343/theseclothes-will-let-you-decompose-in-stylish-grace. Accessed 11 Aug 2016.

Chen, H. L., \& Cluver, B. (2010). Biodegradation and mildew resistance of naturally colored cottons. Textile Research Journal, $80(20), 2188-2194$

Chiappelli, J., \& Chiappelli, T. (2008). Drinking grandma: The problem of embalming. Journal of Environmental Health, 71(5), $24-28$.

Clayden, A., \& Dixon, K. (2007). Woodland burial: Memorial arboretum versus natural native woodland? Mortality, 12(3), $240-260$.

Coeio. (n.d.). Coeio's infinity burial suit. http://coeio.com/. Accessed 11 Aug 2016.

Coeio. (n.d.). Frequently asked questions. http://coeio.com/faqs. Accessed 5 Aug 2016.

Creative Capital. (2015). Jae Rhim Lee Present's [sic] "Infinity Burial Project" at the 2015 Creative Capital Retreat. https:// www.youtube.com/watch?v=|GB08CjHW-Y. Accessed 5 Nov 2015.

Cremation Association of North America. (2015). U.S. cremation rate nearly doubles over past 15 years. http://www. cremationassociation.org/news/254355/U.S.-Cremation-Rate-Nearly-Doubles-Over-Past-15-Years.htm. Accessed 3 Aug 2016.

Davidson, J. M., \& Mainfort, R. C. (2008). Two late nineteenth-century cemeteries in northwest Arkansas: a study in contrasts. Arkansas Historical Quarterly, 67(4), 414-428.

Dholakia, N., \& Zhang, D. (2004). Online qualitative research in the age of e-commerce: data sources and approaches. Forum: Qualitative. Social Research, 5(2), 29.

Doughty, C. (2014). Smoke gets in your eyes: and other lessons from the crematory. New York: W.W. Norton \& Company, Inc.

Elanmugilan, M., Sreekumar, P. A., Singha, N. K., Al-harthi, M. A., \& De, S. K. (2013). Natural weather, soil burial and sea water ageing of low-density polyethylene: Effect of starch/linear low-density polyethylene masterbatch. Journal of Applied Polymer Science, 129(1), 449-457.

Ethel Maid, Inc. (n.d.). Ethel maid history. http://www.ethelmaid.com/history.html. Accessed 11 Aug 2016.

Ethel Maid, Inc. (n.d.). Why burial garments? http://www.ethelmaid.com/whyfashions.html. Accessed 28 July 2016.

Green Burial Council. (2015). Basic tenets for green burial cemeteries. http://greenburialcouncil.org/wp-content/ uploads/2016/02/Basic-Tenets-for-Green-Burial-Cemeteries-2NEW.pdf. Accessed 17 July 2016.

Green Burial Council. (2016). The science behind green and conventional burial. http://greenburialcouncil.org/wp-content/uploads/2016/04/The-Science-Behind-Green-Burial-2.pdf. Accessed 13 July 2016.

Harper, S. (2012). "I'm glad she has her glasses on. That really makes the difference": Grave goods in English and American death rituals. Journal of Material Culture, 17(1), 43-59.

Hauptmann, M., Stewart, P. A., Lubin, J. H., Beane Freeman, L. E., Hornung, R. W., Herrick, R. F., et al. (2009). Mortality from lymphohematopoietic malignancies and brain cancer among embalmers exposed to formaldehyde. Journal of the National Cancer Institute, 101(24), 1696-1708.

Hillestad, R. (1980). The underlying structures of appearance. Dress, 6(1), 117-125.

Hockey, J., Green, T., Clayden, A., \& Powell, M. (2012). Landscapes of the dead? Natural burial and the materialization of absence. Journal of Material Culture, 17(2), 115-132.

Huberman, A. M., \& Miles, M. B. (1994). Data management and analysis methods. In N. K. Denzin \& Y. S. Lincoln (Eds.), Handbook of qualitative research (pp. 428-444). Thousand Oaks: Sage Publications.

Infinity Burial Project. (n.d.). Mushroom death suit. http://infinityburialproject.com/burial-suit. Accessed 30 Nov 2014. Interlandi, P. (2012). [A]dressing death: Fashioning garments for the grave. Melbourne: RMIT University. (Unpublished).

Jurado, V., Porca, E., Pastrana, M. B., Cuezva, S., Fernandez-Cortes, A., \& Saiz-Jimenez, C. (2010). Microbiological study of bulls of indulgence of the 15th-16th centuries. Science of The Total Environment, 408(17), 3711-3715.

Justia Trademarks. (n.d.). Tribute fashions - trademark details. http://trademarks.justia.com/787/01/tribute-fashions-78701718.html. Accessed 10 Aug 2016.

Kellaher, L., Prendergast, D., \& Hockey, J. (2005). In the shadow of the traditional grave. Mortality, 10(4), 237-250.

Kelly, S. (2012). Dead bodies that matter: Toward a new ecology of human death in American culture. The Journal of American Culture, 35(1), 37-51.

Kim, K. H., Hall, M. L., Hart, A., \& Pollard, S. J. T. (2008). A survey of green burial sites in England and Wales and an assessment of the feasibility of a groundwater vulnerability tool. Environmental Technology, 29(1), 1-12.

Kozinets, R. V. (2002). The field behind the screen: Using netnography for marketing research in online communities. Journal of Marketing Research, 39, 61-72.

Kulshreshtha, S., Mathur, N., \& Bhatnagar, P. (2014). Mushroom as a product and their role in mycoremediation. AMB Express, 4(1), 29.

Lugosi, P., Janta, H., \& Watson, P. (2012). Investigative management and consumer research on the internet. International Journal of Contemporary Hospitality Management, 24(6), 838-854

Mark Mitchell Burial. (n.d.). About. https://mark-mitchell-9vfm.squarespace.com/about. Accessed 8 Dec 2014

Marsden, S. (2013). Dressing the dead-Pia Interlandi. https://www.youtube.com/watch?v=gDM3ACHuckQ. Accessed 16 July 2015.

Marsden, S. J. (2016). Green burial sites in the United States. http://www.us-funerals.com/funeral-articles/directory-ofgreen-burial-sites-in-the-united-states.html. Accessed 10 August 2016.

McCausland, C. (2008). Burial out of the box. Alternatives Journal, 34(1), 6.

McDonough, W., \& Braungart, M. (2002). Cradle to cradle: Remaking the way we make things. New York: North Point Press. Merriam, S. B. (2009). Qualitative research: A guide to design and implementation. San Francisco: Jossey-Bass.

Merriam, S. B., \& Tisdell, E. J. (2016). Qualitative research: A quide to design and implementation. San Francisco: Jossey-Bass.

Mitchell, J. L., Carr, D. J., Niven, B. E., Harrison, K., \& Girvan, E. (2012). Physical and mechanical degradation of shirting fabrics in burial conditions. Forensic Science International, 222(1), 94-101. 
National Funeral Directors Association. (2015). Trends and statistics. http://nfda.org/about-funeral-service-/trends-andstatistics.html. Accessed 28 Feb 2016.

National Funeral Directors Association. (2016). Green funerals and burial. http://www.nfda.org/consumer-resources/ planning-a-funeral/green-funerals-and-burial. Accessed 11 Aug 2016.

O'Connor, K. (2013). A fashion line that'll help your corpse decompose in style. http://www.wired.com/2013/09/2110apwhattowear_burial/. Accessed 11 Aug 2016.

Pangallo, D., Kraková, L., Chovanová, K., Bučková, M., Puškarová, A., \& Šimonovičová, A. (2013). Disclosing a crypt: Microbial diversity and degradation activity of the microflora isolated from funeral clothes of Cardinal Peter Pázmány. Microbiological Research, 168(5), 289-299.

Picton, J. (2009). Cloth and the corpse in Ebira. Textile, 7(3), 296-313.

Rita Barber, Inc. (2014). Vera Lee Garments and Woven Remembrance announce that they have purchased Rita Barber of Abilene. https://www.ritabarber.com/news/article/vera-lee-garments-and-woven-remembrance-announce-thatthey-have-purchased-r. Accessed 8 Dec 2014.

Rita Barber, Inc. (n.d.). About us. https://www.ritabarber.com/about/about-us/. Accessed 8 Dec 2014

RMIT Architecture \& Design. (2013). Prs-Pia Interlandi: [A]dressing death: Fashioning garments for the grave. https:// vimeo.com/81684888. Accessed 16 July 2015.

Roach-Higgins, M. E., \& Eicher, J. B. (1992). Dress and identity. Clothing and Textiles Research Journal, 10(4), 1-14.

Ruixuan, Y. (2010). Water-soluble polymers have bright prospects. China Chemical Reporter, 21(17), 30-31.

Solazzo, C., Dyer, J. M., Clerens, S., Plowman, J., Peacock, E. E., \& Collins, M. J. (2013). Proteomic evaluation of the biodegradation of wool fabrics in experimental burials. International Biodeterioration \& Biodegradation, 80(1), 48-59.

Stake, R. E. (1994). Case studies. In N. K. Denzin \& Y. S. Lincoln (Eds.), Handbook of qualitative research (pp. 236-247). Thousand Oaks: Sage Publications.

Stansberry, D.W. (2004). Burial practices in Southern Appalachia. Unpublished Master's Thesis. Johnson City: East Tennessee State University. UMI number 1423909.

Stone-Francois, M. (2013). Mark Mitchell: burial. https://vimeo.com/77758138. Accessed 13 July 2015.

Stowe, J. P., Schmidt, E. V., \& Green, D. (2001). Toxic burials: The final insult. Conservation Biology, 15(6), 1817-1819.

The Forever Spot. (n.d.). The forever spot by Coeio. http://theforeverspot.com/pet-burial-products/. Accessed 11 Aug 2016.

Touchette, B., Schanski, M., \& Lee, S. (2015). Apparel brands' use of Facebook: An exploratory content analysis of branded entertainment. Journal of Fashion Marketing and Management, 19(2), 107-119.

Trompette, P., \& Lemonnier, M. (2009). Funeral embalming: the transformation of a medical innovation. Science Studies, 22(2), 9-30.

Xue, Y., Hezhong, T., Yan, J., Xiong, C., Pan, T., Nie, L., Wu, X., Li, J., Wang, W., Gao, J., Zhu, C., \& Wang, K. (2016). Present and future emissions of HAPs from crematories in China. Atmospheric Environment, 124, 28-36.

Zimmerman, R. (2013). DIY death: Natural, at-home funerals and their boomer appeal. http://commonhealth.legacy.wbur. org/2013/11/diy-death-natural-home-funerals. Accessed 11 Aug 2016.

Zinn, K. (n.d.). Burial clothing. http://www.heart2soul.com/burial-clothing. Accessed 8 Dec 2014.

\section{Submit your manuscript to a SpringerOpen ${ }^{\circ}$ journal and benefit from:}

- Convenient online submission

- Rigorous peer review

- Immediate publication on acceptance

- Open access: articles freely available online

- High visibility within the field

- Retaining the copyright to your article

Submit your next manuscript at $\mathbf{s p r i n g e r o p e n . c o m ~}$ 